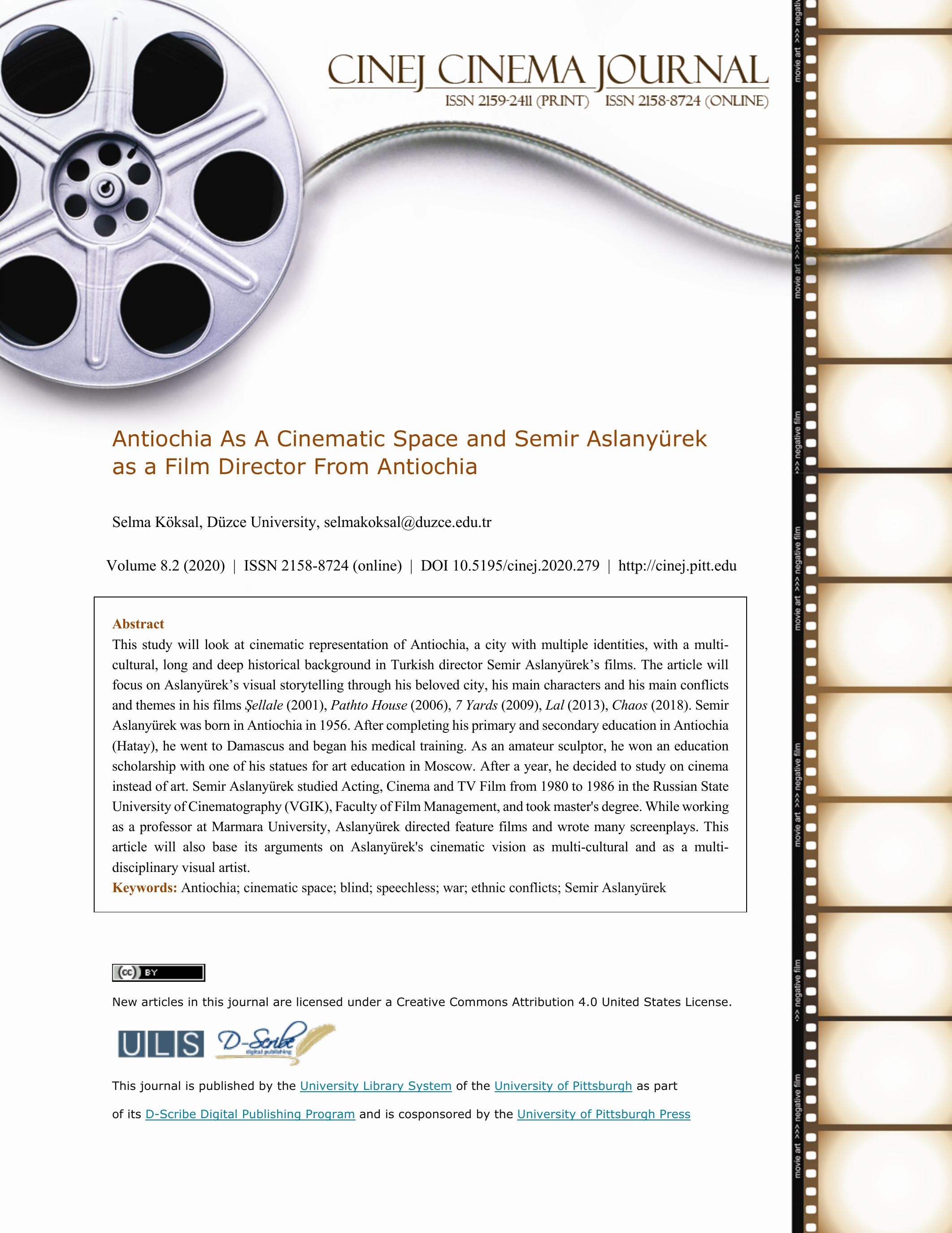




\section{Antiochia As A Cinematic Space And Semir Aslanyürek As A Film Director From Antiochia Selma Koksal}

\section{Introduction: Semir Aslanyürek As a Film Director}

Semir Aslanyürek was born in Antiochia (also known as Antakya or Hatay is Turkish) on 15

August 1956. He has described Antiochia and the recent history of the Republic of Turkey in his

films. Aslanyürek is regarded as an auteur- director who has created an original language of

cinema by telling the stories of the people of Antioch, their conflicts, their difficulties and the

nature of Antioch together with the lands and political history of Turkey. A film "auteur" is a

director who transfers his/her own style, perspective and ideology to his/her film work in a

different way than other film creators. A film director who has a lot of influence on the making

of their films, so that they can be considered as their author (Aitken 2010; Buker 2012). ${ }^{1}$

After completing his primary and secondary education in Antioch, Aslanyürek went to

Damascus in the fall of 1975 and studied at the Medical Faculty of Damascus University until

1978, in these years he won a scholarship from the Soviet Union with a stone statue he made. In

1979, while he was continuing his education in preparatory class, he went to the Soviet Union

and started his film education rather than studying sculpture, and he studied Acting, Cinema and

TV Film from 1980 to 1986 in the Faculty of Film Management of the All Union State Institute

of Cinematography (VGIK) in Moscow, and took master's degree. In this Institute of 
Cinematography, he has made short films called Yara (Wound), Babil'de Yalnuzllk (Alone in Baylon) and Yukarda Havalar Temiz (The Air is Clean Up There). After returning to Turkey in the later 1986, Aslanyürek experienced the pressure of the political environment after the military coup d'état, and after 18 months of military service, he spent two years in Antiochia by dressing stones (sculpturing) to earn his living. He started his career as a lecturer at Marmara University, Faculty of Fine Arts, Department of Cinema and Television in 1990, and shot his first feature film Vagon (Wagon) in 1993, but he could not complete its post-production works. After he shot his second feature film, Şellale (Waterfall) in 2001, he was awarded the title of Associate Professor in 1995 and Professor in 2002. In 2003, he made a documentary film called Çağlar İçinde Antiochia (Antioch Across Ages). He also shot his third feature film, Eve Giden Yol 1914 (Road to Home) in 2006.

Semir Aslanyürek has published books on filmmaking and film theory such as Senaryo Kuramı (Theory of Screenplay, 1998), Bir Dă̆ Düğ̈̈nü (A Mountain Wedding, 2007), Tarkovsky'den Sinema Dersleri (Cinema Lectures by Tarkovsky, 2012), and Rüya Gibi: Sovyetler Birliği'nde Yedi Yll (Like A Dream: Seven Years in the Soviet Union, 2013). He also has completed nine feature-length scripts, two of which are spin-off, and a translated book from Russian called Sinema ve TV'de Görüntü Kurgusu (Editing in Film and Televison). The director, who speaks Arabic and Russian, reflects the multilingual and multicultural structure of Antiochia 
in his films, with a warm and humorous language of cinema, by telling us Antiochia's

extraordinary nature and beauty, which is shaken with wars, ethnic conflicts, unrest and chaotic

processes.

According to Murray Bookchin, the term "city air makes people free" refers to personal and political freedom, as well as freedom of thought and being innovative (Bookchin; Ozturk)). In this context, Semir Aslanyürek freely reflected Antiochia, one of the freest cities in Turkey, to us in his works. Semir Aslanyürek's cinema has a wide panorama of Turkey intertwined with Antioch. Aslanyürek shot all of his films in Antiochia except his first film Vagon, and he is a wise director who has dedicated his life to reflecting the people of Antioch and their dilemmas to us without forgetting the realities of Turkey. In this study, the director's five feature films Şellale, Eve Giden Yol, 7 Avlu, Lal ve Kaos are discussed within the context of his view of historicity, the heroes he created and conflicts.

\section{Şellale/Waterfall (2000)}

The director's second feature film, Şellale, is produced in 2000 and takes place in 1960. The film begins with the dream images of a young painter (Cemal) who always has the same dream and identify the waterfall with what he lost years ago. In fact, it is more than a dream, it is nightmares 
and missing parts of the past that followed him all his life. The painter expresses his longing for the extraordinarily beautiful and fertile land of Antiochia which has a long and complex history to his mother by saying that; "Mother, I want to return to Antioch, where I lost the Defne".

It is May 1960. "We have sent the French, and now we brought Uncle Sam," Berber Selim Usta says, pointing to the arms of another kind of occupation, the arms of imperialism, which spread to Antiochia and all over the country. He laments that "uncle Sam has taken tens of thousands of Turkish Republic young people to fight in Korea as soldiers by distributing milks made from milk powder for children, and flour and similar things. Now Turkey is a NATO member and this has a price"2. In the film, pro-CHP ( Republican People's Party) Süleyman and his brother who is a member of Democratic Party bring their political discussions to such a harsh point that they eventually build a wall that separates them and their families in the courtyard of their common house. Their arguments continue unkindly throughout the film, disturbing the peace of their families and children, and increases. Despite the built wall, they always argue. Süleyman, who is a social democrat, is not a democrat against his children and his wife at home.

Patriarchal family structure always affects them. Süleyman says "they made us to enter a war with two cups of donkey milk”. His brother accuses İsmet İnönü, who was the prime minister of that period for many years and then the main opposition leader, for being a communist and a dictator. Fight and argument between the two brothers always continue. 
However, Süleyman is unemployed, and his brother cannot get his money from the construction sites where he works as a foreman. Financial difficulties and silly investments make its mark on the period. The party members, who dynamite the source of the waterfall (Şellale), which is plentifulness of Antiochia, dry the waterfall to get more water. The waterfall becomes a metaphor for the wrong and brutal interventions to the country's resources. We watch the whole movie from the eyes of young boy Cemal and his sister. Yusuf shows his brother a Roman period God statue in the cave. Cemal, who sees extraordinary statues and mosaics during his school trip, is fascinated by the historical past of Antiochia. These memories, which will deeply affect his artistic personality, will be effective in forming Cemal's artistic identity.

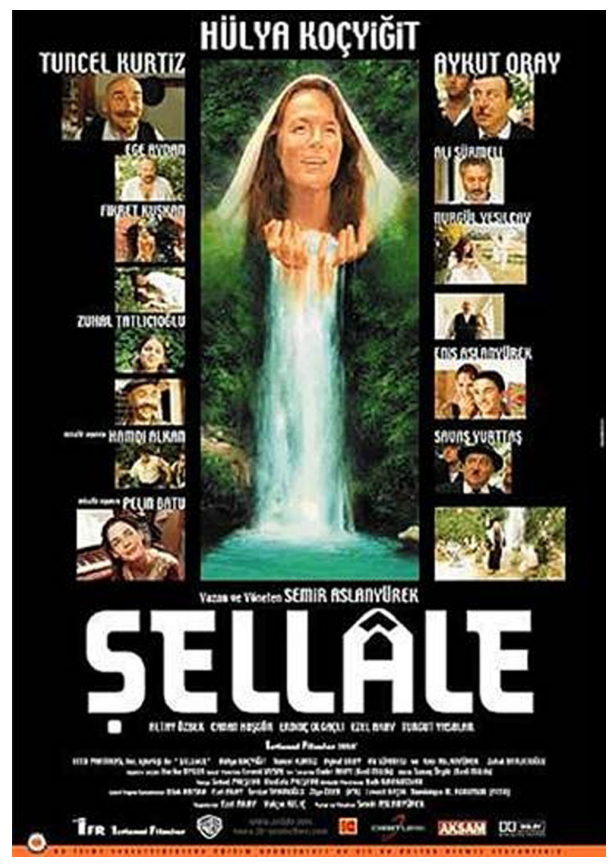

Figure 1: Sellale (Waterfall) Film Poster 


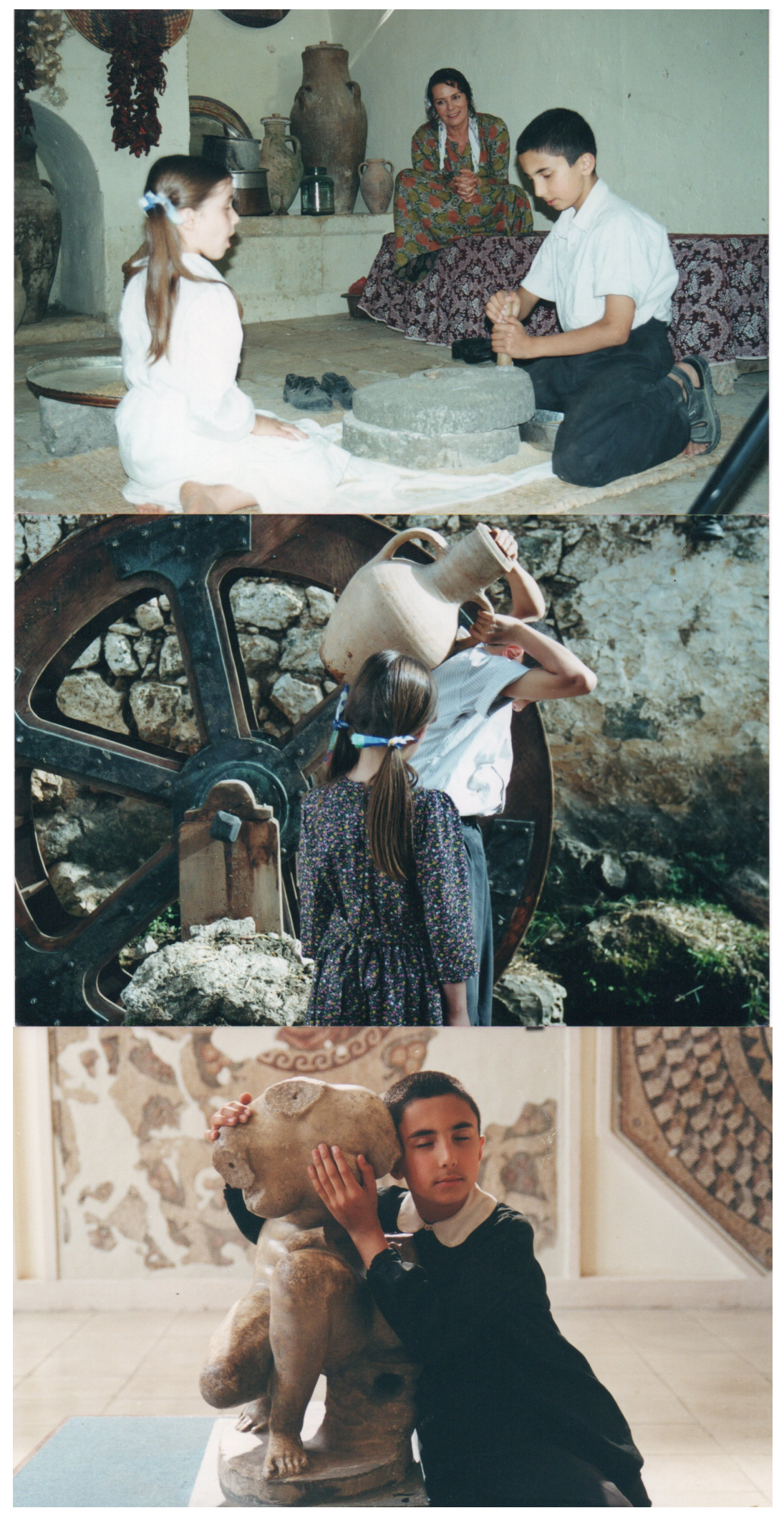

Figure 2: Child characters of Sellale 
Throughout the film, harsh political views, political polarization and difference of opinion between individuals will cause conflicts constantly. The trickster butcher sees no moral problem in selling the people cat meat or donkey meat. They constantly have a row with the barber, who is an admirer of Stalin and the socialist order created in the Soviets at the time. The waterfall, which brings together all the people of Antiochia from time to time and it is a feast place, is also a pleasant conversation environment, and these conversations end with chair and table fights with the drunk and sober people. However, beauty and abundance are right next to them. They don't know how to share that fraternally, have fun and communicate. This scene, which directed in a carnivalesque way, also has a high sense of humor. A kind of irrationality, getting mad situation is always observed in the family, in the village and in the townspeople. Conflict, fighting and war are madness; this is highlighted and criticized in all of Semir Aslanyürek's films ${ }^{3}$.

Humor is everpresent in Aslanyurek's narrative For example, Laika, the first animal sent to the space with a space vehicle, is identified as "the communist dog" by one of the characters. One of the humorous aspects of the film is that the couple who married after a big love chase each other throughout the film. However, at the end of the film, Adnan Menderes, to whom İsmet İnönü said “one day will come and even I won't be able to save you”, is deposed by a 
military coup. The terrifying result will soon be realized. Cemal's younger sister, who died of poverty and lack of care, is almost a representation of this period as a "victim". The young woman, who refuses to make love with her husband throughout the film, gives herself to her husband at the end of the film. Life somehow goes on despite all the pain. Two brothers destroy the wall they have built. After that what will happen in the country? Is it possible to find a communication way or a solution? The film ends with these questions.

\section{Eve Giden Yol 1914/The Way Home (2006)}

The director's third feature film produced in 2006, is Eve Giden Yol 1914 (The Way Home). The film begins with the scene of a massacre in a village near Antiochia around 1914, the last years of the Ottoman Empire. In this massacre, which carried out as a result of ethnic and sectarian problems, the young girls of the village are raped and these young girls are released. Within the scope of the honor concept, the village elders and locals do not allow the birth of the bastard children of the young girls, and it is decided that the girls will die by throwing them into the "blood well". In order to realize this, they make a fraudulent stone draw, this task is given to Mahmut, main character of the film. Mahmut, who is in love with Safiye, the daughter of Servet Agha, cannot kill the girls and releases them. However, Halluş, the son of another agha who loves Safiye, prevents Safiye and Mahmut's marriage during the entire film. 
The life of Mahmut, our main character who is at the center of this epic story, will take its share from the painful history of the period by moving from place to place with the ethnic, sectarian, cultural and class conflicts and with the wars of the Empire which is at the center of a terrible historical process. Since he did not have an identity card, he is sent to the army in the name of Halluş after the declaration of mobilization. It is very hot in the desert and there is hunger and misery. Ottoman soldiers tragically fight with "lack of equipment and starvation" in Palestine, the Sinai Desert and the Suez Canal. İffet, the wife of Agha, forced herself on Mahmut in a rape like scene. Returning to Antiochia after French occupation, with unpleasant war experiences, Mahmut comes together with Safiye, whose father is killed by a trap. But both of them have many painful experiences. Eve Giden Yol, like all other Semir Arslanyürek films, shows parallelism with themes of basic narratives of world literature, such as 1001 Nights and The Decameron, with the concepts of "the journey back", "bitter experiences", and "the treasure is in fact in your own homeland and home".

\section{Avlu/7 Yards (2009)}

Semir Aslanyürek's fourth feature film, 7 Avlu (2009), is a very simple film, shot with a script which has very strong and humanistic elements. After Sellale and Eve Giden Yol, in this film, the 
director, who wrote all his scripts himself, focused on domestic (family) lives of the courtyards in Antiochia, where he chose as a location again, with a simpler cinematic narrative. The story of the film is a recent history of Antiochia and Turkey trying to join the European Union.

In Antioch, courtyards are separated from the streets with high walls. The courtyard houses separate the people, who live in these houses, from the others with high walls and an outer doors opening to the streets. In these courtyard houses, Turks, Armenians, Jews, Greeks, Kurds, Arabs, Sunni Muslims, Alevis and other ethnic groups live as families. They live with their own traditions, and a different language is spoken in every courtyard.

In this film, Eleni is a 27-year-old widow woman of Greek origin, she has three daughters, and she is a Christian. After her husband's death, she has been alienated by her neighbors. Men have stopped speaking with her in order to avoid gossip, while the women do the same intending to keep her away from their husbands, and she gets lonely. Eleni's eldest daughter does not want to marry, she wants to go to school and realize herself, and wants a life different from the one her mother wanted for her. Eleni speaks with her daughter in Greek language and her daughter insistently replies her in Turkish, and this is repeated throughout the film, and other parents and children of other ethnicities do the same. The new generation insist on speaking Turkish and being a part of this country and their parents do not want to respond to their wishes to protect their culture and language. 
Every night, Eleni visits these seven courtyard houses on her street and asks her neighbors for a piece of lemon, saying that she cooked stuffed grape leaves, chicken, cheesy kunafah, has soda and needs a piece of lemon for her soup, but each time they slam the door in her face. The film starts with a very impressive dialog. Jewish Goldsmith Azra is forced by his mother to get divorced from his wife Selma and marry with a girl from his own community, and according to his mother, to do this, he must choose a girl of a more suitable age who lives in cities such as New York or London. Otherwise, her mother threatens Azra to disinherit him. But Azra's mind is very clear about this. He clearly expresses his pessimistic thoughts about the civilization created by humankind, by saying that he does not want to have children, and that the child he brought into the world will be killed or kill someone. He also adds that they have lived here for 5,000 years, that he would not live this place, and that the plants, animals and people of Antiochia are his own relatives. These sentences are like the summary of the deep ties of Semir Aslanyürek's cinema with Antiochia. Each courtyard in the film presents common themes.

In coutyard no. 1, we witness the digging process that took hours and days after Yusuf, who had no children, was told by a religious person that Yusuf's fortune was in his own courtyard, at the bottom of a cut palm tree. But the treasure found by Yusuf and his wife is a mummy from their ancient cultures. In this horrific scene, Yusuf and his wife finish their digging work when Eleni 
knocked the door and immediately they open the door to Eleni, and they refuse her request of a piece of lemon.

In courtyard no. 2, there is a couple who have mental retardation. In their courtyard, they dream together and try to have children by riding in a Mercedes car they have never been able to use. Although the man has mental retardation, he mockingly tells his wife that he made a lot of money, because of this money he earned even the mayor had to respect him and button up his jacket when he saw him. There is not much need for intelligence to make money and the power and prestige that money brings. Semir Aslanyürek makes a humorous criticism of today's values with such an allegory in these days in which money and power are glorified. Eleni knocks on the door, and this couple doesn't share a piece of lemon with her.

In courtyard no. 3, Greek, Armenian and Turkish old revolutionaries talk about old days and sing revolutionary songs at the drinking table. They talk about the iconic subjects of the period such as CIA, idealism, revolutionism and TOBDER (All Teachers Association for Unification and Solidarity). They criticize their failure about September 12 military coup d'etat, which they could not foresee, as one of the biggest reasons why they failed to carry out the revolution. Mr. Sami adds that a revolution requires money and that a revolution without money is impossible. A real "revolution consciousness" is required for the revolution. His former revolutionary friends were candidates from right-wing parties and they are elected. They self-criticize by saying 
themselves "aquarium left-wingers". The young woman, who unwillingly serves the men's drinking table, is harassed by one of the married male guests at the table, she sticks the knife, and Eleni knocks on the door. They don't have a piece of lemon to give her.

In courtyard no. 4, a Christian family of Armenian origin lives in the courtyard. Aram, father of the family, is tired of working, and because of the laziness and regardless of his young children, he complains about his troubles to his friend who speaks excellent Armenian.

Moreover, his children never try to speak their own language. His son, who studies in high school, decides to get married and drop out of school. He will make no effort to make money while his father is alive. The little boy asks for one lira from his mother, when his mother does not give him the money, he pees around, the father gets very angry, he wants to burn the house, mother faints, during this scene, the two young children, who are on their summer vacation continue to play chess without reacting. Eleni knocks on the door in the middle of this chaotic situation. But this family also doesn't have a piece of lemon to give her.

In courtyard no. 5, there is an interesting marriage and their children live a terrible life.

While the Kurdish mother tries to live her own life at the dinner table with her sons and daughters-in-law, the Turkish father constantly humiliates the Kurdish mother and her sons and he is drunk as a skunk. The sons tie up their father, but when he tells them that they are bastards 
and their mother is whore, they decide to kill their father. In the meantime, Eleni knocks on the door and asks for a piece of lemon, saying that she cooked stuffed grape leaves, chicken, and cheesy kunafah (a local dessert). Unfortunately, she cannot get a piece of lemon from this courtyard house either.

In courtyard no. 6, Azra comes home with a bag full of money. His deaf and mute wife, Selma, tries to attract the attention of her husband, who passes through the courtyard without paying any attention to her and starts counting money. But Azra must count the money he will deposit in the bank Monday. Selma, trying to live in the moment and needing her husband's attention and kindness, begins to cry by climbing the tree. When Azra tries to convince Selma to climb down the tree and apologizes to her, Eleni knocks on the door. Azra scolds Eleni, Selma comes with a piece of lemon but cannot catch her.

In courtyard no. 7, the old and lonely Mürşit talks to the ghost of his wife, whom he lost years ago, and reviews for their disagreements and miscommunication. His wife Ayla is always silent and looks away. Uncle Mürşit, who is unable to communicate and explain himself, decides to hang himself. He prepares the rope, puts it around his neck. At this very moment, Eleni knocks on Uncle Mürşit's door. Uncle Mürşit can't understand what Eleni wants, he brings other things. Finally, when he came with lemon in his hand, Eleni is gone. 
At her home, Eleni prays to the Virgin Mary in tears presenting the audience with the universalist message of the director as follows; "Why are we suffering? Why are people so cruel, why do they behave badly each other, when will we learn to be happy? Aren't we all children of God? Aren't Turks, Armenians, Jews and Arabs all children of God? Why does God allow cruelty?" .

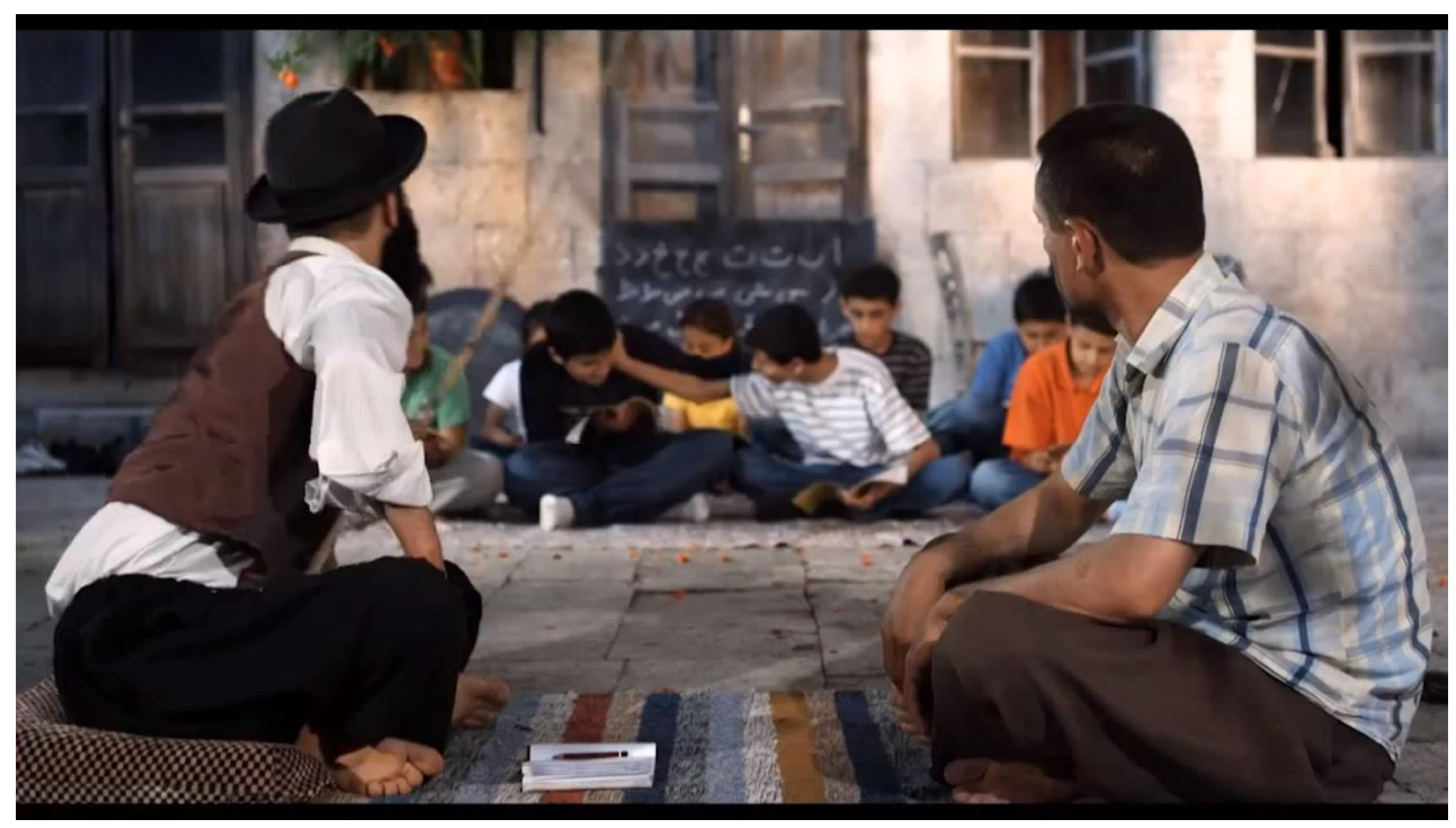

Figure 3: One of the courtyards in 7 Yards.

\section{Lal/Speechless (2014)}

Lal made in 2014, is the director's another feature film that started and continued on the eve of the 1974 Turkish military interference in Cyprus as a peace operation. The film begins with 
agency news coming from the radio. Prime Minister Ecevit explains the reasons for the operation. Morning hours in Antiochia. The film continues with the scene in which the children play war games with rifles made of wood. The militaristic atmosphere of the period has influenced children.

The father of Süleyman, one of the film's two young main characters, lives in Germany, has left Süleyman and his mother, and lives with a German woman. He left Süleyman and his mother "speechless (lal)", who had come to the point of losing her mind from loneliness. Süleyman refuses to speak, and he becomes an object of derision of all children and the people. The film continues with scenes of condolence at the funeral of a martyr. It is secretly discussed whether the deceased is a martyr or a deserter. As in all Semir Aslanyürek films, also in this film the inter-family unrest continues for generations.

In İncirlik, Adana, the leftist militant revolutionary filmmaker Yılmaz Güney is making the film of Endişe (Anxiety). A minibus driver who has a photo with Yilmaz Güney tells the people about Yılmaz Güney. Cemal, our other young main character who witnessed these conversations, offers to Süleyman to go to Adana and take a photo with Y1lmaz Güney. Cemal receives praise from Safiye, who lives next door and whom he is in love, by projecting a movie scene of Yilmaz Güney to the wall with a black box he made himself. Süleyman ve Cemal steal a camera from Beşir's photo shop (with their own words they borrow it), and they take the road. 
Süleyman and Cemal, who are speechless, poor, disabled and lonely, show their anger to the mountains on the road. The road is tiring and hard. They lose their way in the misty valley. The Blind Clairvoyant show them their way in the misty valley Like all Semir Aslanyürek films, in this film the unique beauties of Antiochia and its surroundings, Asi River, Samandağ and valleys adds extra beauty to the visual language of the film.

From agency news shown in the film from time to time, we understand that the economic problems of the period were serious. Some animals die of starvation. And people are in a very bad situation. These characters meet up with melon seller Ali on the way. Ali tells them that his father died as a result of sunstroke, that he was a smuggler in his previous life, and that he was ambushed and killed in a job that he took his son Cafer with him. Then they meet with Cafer whom he claims to be his son in his previous life. Ali entrust them to Cafer, asking him to keep an eye on them on the way. And he gives them a statue to give it to Y1lmaz Güney.

Cafer and our heroes take the road. They ask Cafer that if he is Ali's son. Jafar answers positively. Ali was his father in a previous life and was shot in the head near him. But this time Cafer becomes suspicious from an ambush and recommends them to hide. He gives his tasbih them to give it to Yılmaz Güney. And the gendarmerie arrests Cafer and takes him away. 
Lal is a filmic narrative in which real and surreal elements are intertwined. The mystical and the real are presented together to the film lovers throughout the film. The narrative tradition of ancient Anatolia has created a unique fairy tale narrative tradition by intertwining the subconscious and the overconscious. Aslanyürek takes full advantage of this tradition of his own land and makes his own language.

When the shepherd girl learns that they are going to Adana to take a photo with Yilmaz Güney, she gives her hand-painted kerchief to them to give it Y1lmaz Güney, and she shows them the way of Adana. Y1lmaz Güney is an artist who has reached out to all these people they have met during their journey, gained their love, made his art available for these people and became a legend. There is no doubt that Aslanyürek's Lal is also a tribute to Yilmaz Güney and his cinema.

While taking bath in the river our heroes are questioned by the young people they saw. They ask them where they come from, where they go and whether they are rightist or leftist. They guess that they are leftists, and they give these young boys a beating. Cemal tells Süleyman that "if someone beats you because you are a leftist, purposely you will be leftist". When they reach the city, they find themselves in a demonstration march against American imperialism. They are beaten with the group that has been attacked by right-wingers. They go to the mosque and pray with the old man who takes them to prayer. They find themselves in a police station, 
after a police raid together with the people who are trying to enter the iron and steel factory as workers. Süleyman survives of birching because he is speechless, but Cemal is not so lucky. He's been badly beaten and his health is very bad. At the end of their journey, his life also ends. Unfortunately, Y1lmaz Güney has been imprisoned because he killed a public prosecutor, and could not finish the film. Süleyman, who started to talk, is in front of a banner with a picture of Yilmaz Güney, but he can't bring his friend back to life. The film ends.

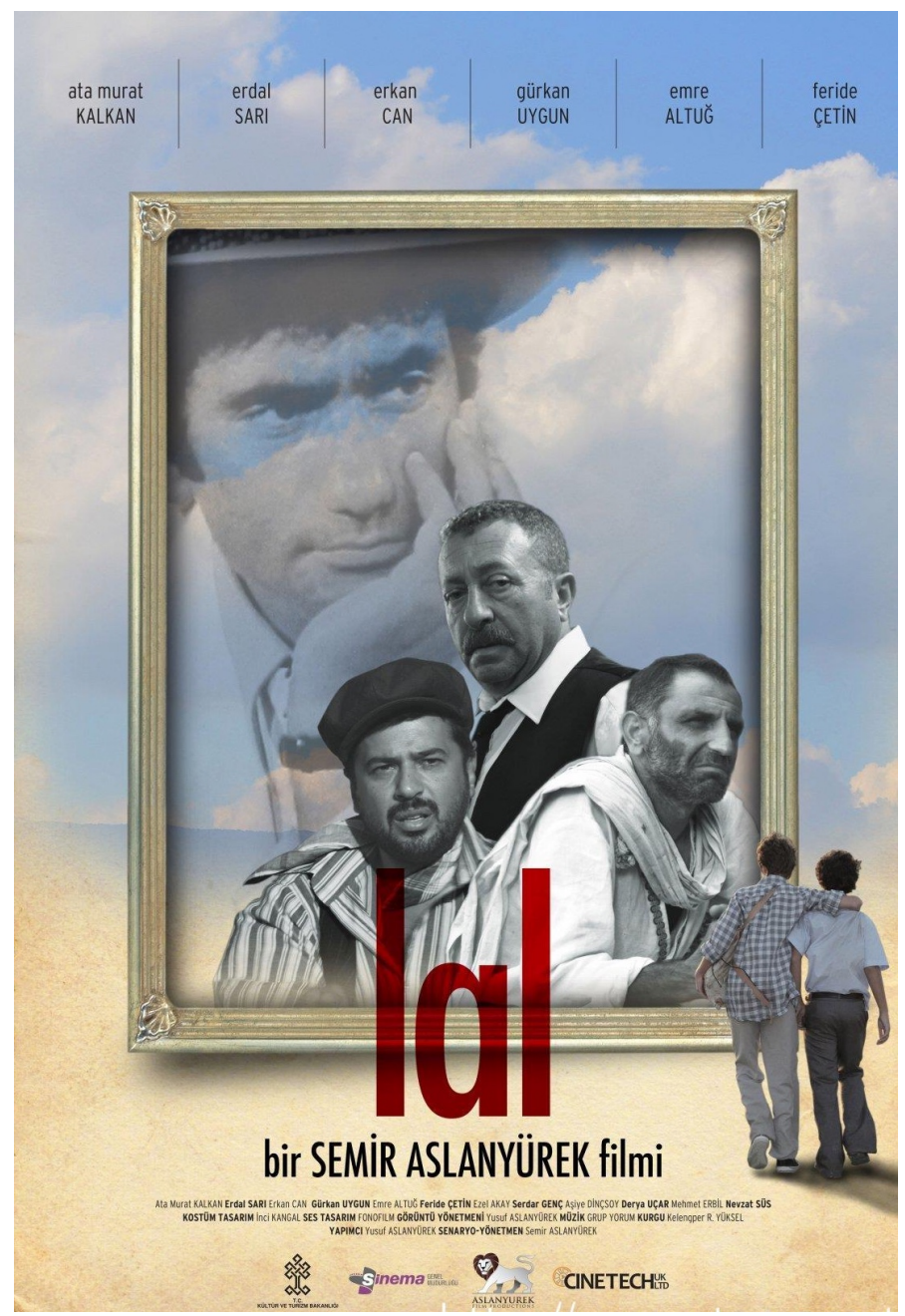

Figure 4: Poster from Lal/Speechless 


\section{Kaos/Chaos (2017)}

Unfortunately, Semir Aslanyürek's latest film Kaos (Chaos, 2017) has not yet had a chance to come to the theaters. However, the script of this film, in which three guilty men meet in a cave and are stuck because of an earthquake, is an extraordinary script written by Aslanyürek with the wisdom of a holy person, and it is the last film shot in such calmness.

Kaos tells us the period in which Franks constantly provoke bandits, and there are political disorders, raided villages and unmerciful aghas in this film. Hasan Agha promised to marry Zehra, 13-year-old daughter of Barber Naci, to another man without asking her. He does not accept the objections of the Barber Naci, and sends his head to his family after beheading him. Young son, who is promised to marry with the daughter of Barber Naci gets very angry and kills Hasan Agha in an ambush. However, he cannot bear the pain of killing a human, and hides in a cave with a shivering crisis like malaria. The two other men who took shelter in the cave are not different from this young man.

Saffet has lost his mind and got lost while fighting in the deserts of Yemen. His wife, Fadime, who has been waiting for him for years, protects herself from men and waits for the arrival of her husband for years. Saffet, who comes home like a stranger and becomes a guest of Fadime and forcibly shares her bed, does not even hear that his wife will recognize him as soon as she sees him and announce his arrival to the city in the morning with joy. He is in such a 
terrible emptiness and darkness that he can't even hear. The reward for his wife waiting for him for years is to be killed by Saffet.

Sheikh Abdullah, the leader of blind beggars who hear that all bandits are raiding everywhere, ties the blind beggars together (whom he had them begged by taking advantage of their blindness by having them read Quran for years), and flees to the mountains with a donkey. The main purpose of Sheikh Abdullah and the blind beggars is to go to the city. However, he takes all the saved money with him and flees, leaving this blind, needy and half-wit group, whom he describes as zindik (atheist), alone on the mountain. In this scene, which is perhaps one of the most allegorical and powerful scenes of all Semir Aslanyürek films, these blind atheists are deserted on a mountain after they are robbed. Firstly, these atheists (zındık) who can't decide what to do get into fight with each other. Then a sensible atheist says that their only solution is to go back to their dervish lodge, that they need each other, and that the only living thing that knows the way is the donkey. Actually all atheists prefer to go to city, but if they do not lead the donkey it will turn back to its home, in other words to the lodge. Desperately, they decide not to go to the city, and they follow the donkey which walks towards its home after they released it. This scene is perhaps the most accurate allegory of modern-day Turkey. Together with the donkey, the blind beggars begin their journey back home. Crime has reached the hands and 
souls of Saffet, Abdullah Agha, and the young murderer. They have been trapped in the cave after the earthquake.

Aslanyurek, as a director who was born in Antiochia, tells us his hometown, its rivers, nature, caves, bridges, courtyard houses and other things which looks like a heaven, and he shows us the remains of civilizations that have been living in Antiochia for thousands of years as a visual feast with a great narrative of cinema. However, despite all these unique beauties and fertile lands, the people of Antioch, who belong to different ethnicities and have different languages and beliefs, are unable to share this heaven in peace and live with tolerance. Of course, one of the main reasons for this is not only global wars, but also the problematic nature of human nature. People always prefer to establish their own sovereignty by choosing selfishness and alienation.

The heroes of Aslanyürek cinema are epic narrative heroes. They move from place to place as experimental heroes in the chaos of historical processes and political and economic problems. Their fate is determined by the realities of the time and space they are in. From time to time, the elements of realistic cinema intertwine with the epic elements of the ancient Anatolian narrative. Semir Aslanyürek, who chooses ordinary people as heroes, directs his camera at his heroes with an objective distance. He rejects an emotion-centered Aristotelian approach and prefers an epic 
and thought-centered narrative. His films thoroughly shed light on the history of the Republic of Turkey and Antiochia, beginning from the late Ottoman period.

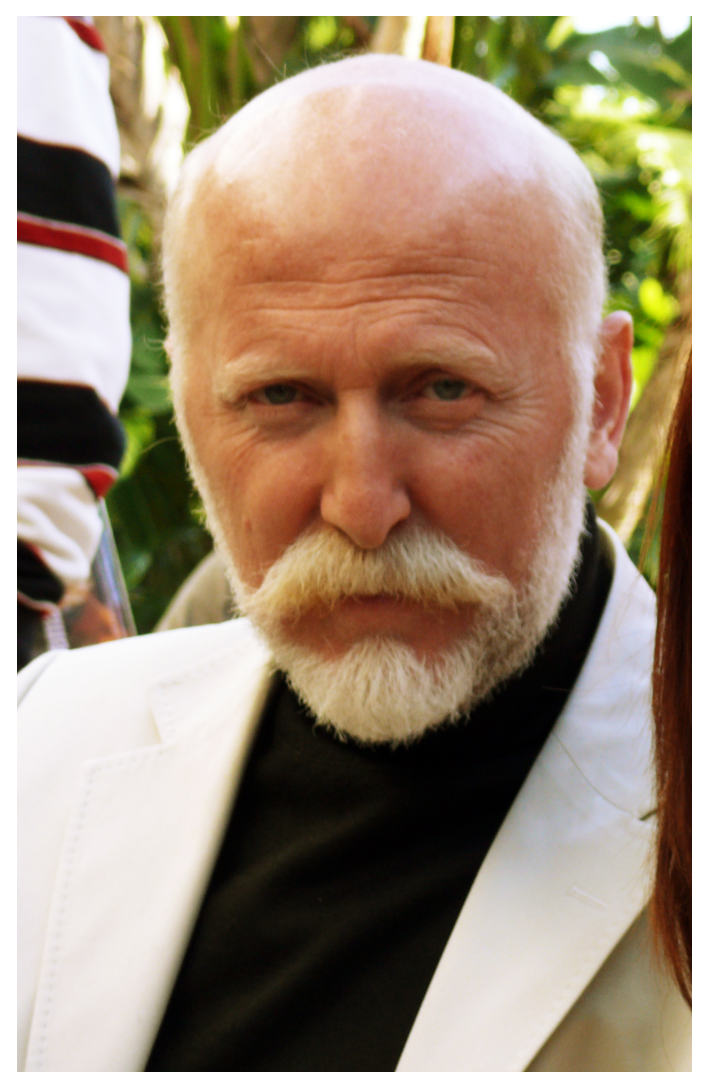

Figure 5: Director Semir Aslanyurek

\section{REFERENCES}

Aitken, I. (2001). European film theory and cinema: A critical introduction. Bloomington: Indiana University Press.

Akser, M. (2013). Auteur and Style in National Cinema: A Reframing of Metin Erksan's Time to Love. CINEJ Cinema Journal, 3(1), 162-180.

Akser, M., \& Durak-Akser, D. (2017). Fight for a national cinema: an introductory text and translation (Halit Refiğ, 1971). Film Studies, 16(1), 56-77. 
Aslanyürek, S. (2013). Rüya Gibi: Sovyetler Birliğinde Yedi Yıl. İstanbul: Pan Yayıncılık.

Aslanyürek, S. (2012). Tarkovsky’den Sinema Dersleri. İstanbul: Agora.

Aslanyürek, S. (2007). Bir Dă̆g Düğ̈̈nü. İstanbul: Chivi.

Aslanyürek, S. (1998). Senaryo kuramı. İstanbul: Pan Yayınc1lık.

Bakhtin, M. M. (1984). Rabelais and his world. Bloomington: Indiana University Press.

Behlil, M. (2012). East is East? New Turkish Cinema and Eastern Europe. In Imre, A. (Ed.). A companion to Eastern european cinemas, (504-517). Wiley-Blackwell.

Büker, S. (2012). Sinemada anlam yaratma. Ankara: Hayalperest.

Bookchin, M. (1974). The limits of the city. New York, NY: Harper \& Row.

Connon, D. (2017). Towards a Theory for African Cinema (Férid Boughedir, 1974). Film Studies, 16(1), 78-88.

Daldal, A. (2017). Ceylan's Winter Sleep: From Ambiguity to Nothingness. CINEJ Cinema Journal, 6(2), 181-199.

Hefner, B. (2014). Milland alone: the end of the system, post-studio stardom, and the total auteur. Journal of Film and Video, 66(4), 3-18.

Keskin, S., \& Baykan, B. (2020). Becoming-Animal in the Narrative and the Form of Reha Erdem's Kosmos. CINEJ Cinema Journal, 8(1), 249-285.

Köksal, S. (2017). Sinemada yapım ve yönetim. İstanbul: Yitik Ülke.

Öztürk, M. (2014). Sine-masal kentler: modernitenin iki "kahramanı" kent ve sinema üzerine bir inceleme. İstanbul: Doğu Kitabevi.

Sayari, S. (2000). Turkish foreign policy in the post-Cold War era: The challenges of multiregionalism. Journal of International Affairs, 54(1),169-182. 


\section{ENDNOTES}

${ }^{1}$ There have been more than one auteur film director in Turkish cinema ranging from Metin Erksan (Akser 2013) and Halit Refĭg (Akser and Durak-Akser 2017) to Omer Kavur, Reha Erdem (Keskin and Baykan 2020) and Nuri Bilge Ceylan (Daldal 2017). Semir Aslanyürek stands as a unique case from a film studies perspective as there is virtually no academic study of the director's ouvre with the exception of brief mention of him in general introduction to Turkish cinema (Behlil 2012). Aslanyürek's rise as an auteur director coincides with the end of classical film production system in Turkey called Yeşilçam (Green Pine) and in a similar way parallels end of classical Hollywood and rise of new auteurs (Hefner 2014). Women characters and actors' performances are also an understudied aspect of Aslanyürek's cinema. Actors like Hülya Koçyiğit, Nurgül Yeşilçay, İrem Altuğ and Feride Çetin gave some of their best performances under Aslanyurek's directon [Editor's Note].

${ }^{2}$ For details on Turkey's foreign policy during the Cold War, please see Sayari (2000) [Editor's Note].

${ }^{3}$ It is interesting to note that Şellale was produced by Ezel Akay of IFR Film at the time. Akay himself is an actor and director with a unique approach to filmmaking that should also be studied in its of right by film scholars [Editor's Note]. 